\title{
Spinal cord tuberculosis: a paradoxical response to antituberculous therapy
}

\author{
Ritesh Sahu, Tejendra S Chaudhari, Vivek Junewar, Rakesh Shukla
}

Department of Neurology, King George's Medical University, Lucknow, Uttar Pradesh, India

\section{Correspondence to} Professor Rakesh Shukla, rakeshshukla_rakesh@ rediffmail.com

Accepted 6 February 2014

\section{DESCRIPTION}

A 22-year-old man, with a known case of definitive tuberculous meningitis (TBM) on antitubercular therapy (ATT) for 5 months, presented with subacute onset sensorimotor paraparesis with urinary urgency since 1 month. He had also received dexamethasone therapy $0.4 \mathrm{mg} / \mathrm{kg} / 24 \mathrm{~h}$ for 1 month followed by reducing course over next 2 weeks as per British Infection Society guidelines. MRI of the spine revealed a ring enhancing intramedullary lesion at D4 level suggestive of tuberculoma alongwith extramedullary meningeal based heterogeneously enhancing lesion extending from D6 to D10 level suggestive of arachnoiditis (figures 1 and 2).

Paradoxical reaction in TBM refers to type IV hypersensitivity reaction manifesting as new tuberculoma and/or arachnoiditis during the course of antituberculous chemotherapy. ${ }^{1}$ The host immune response responsible for hypersensitivity reaction to protein derivatives of mycobacteria is resolved after starting chemotherapy. ${ }^{2}$ As per previous literature, spinal tuberculosis is an unusual complication of TBM. ${ }^{3}$ Spinal cord tuberculosis as a paradoxical immune response should be known as an unusual but a possible complication of TBM. Recommendation

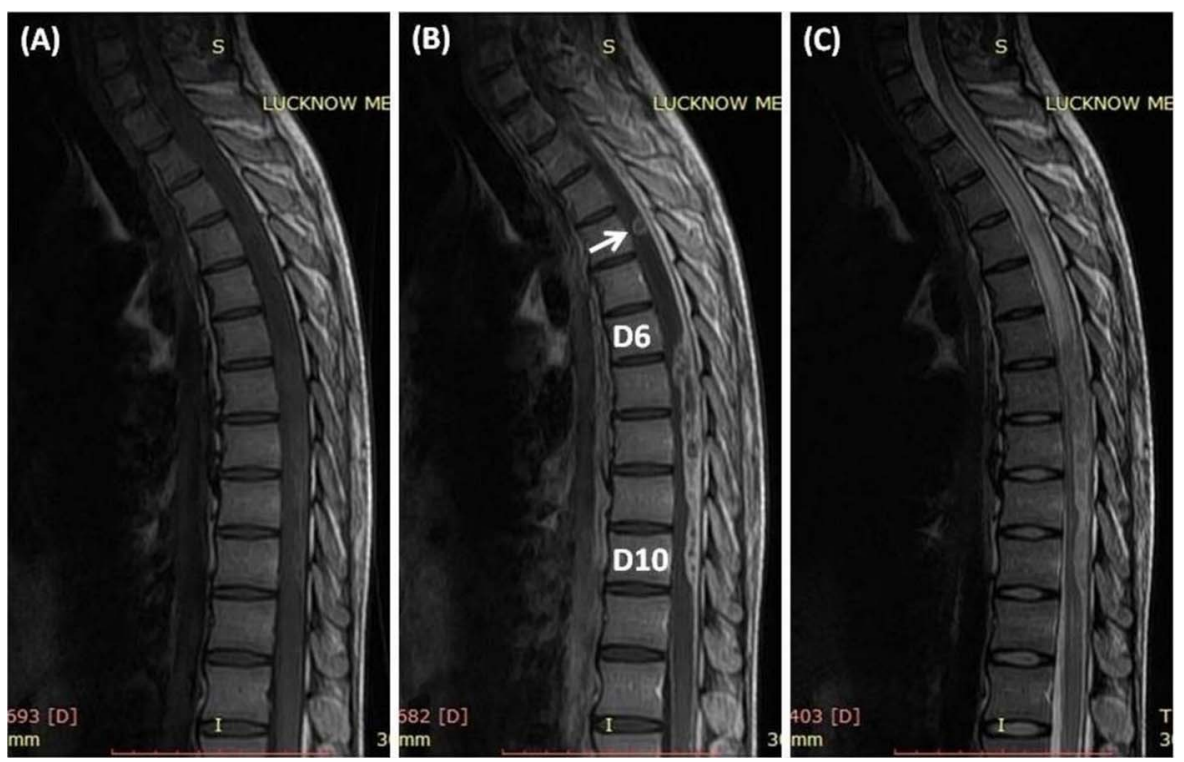

Figure 1 MRI dorsal spine sagittal images (T1-weighted image (A), T1+C (B), T2-weighted image (C)) showing ring enhancing intramedullary lesion s/o tuberculoma (arrow) and extramedullary meningeal based heterogeneously enhancing lesion with cord compression s/o arachnoiditis.
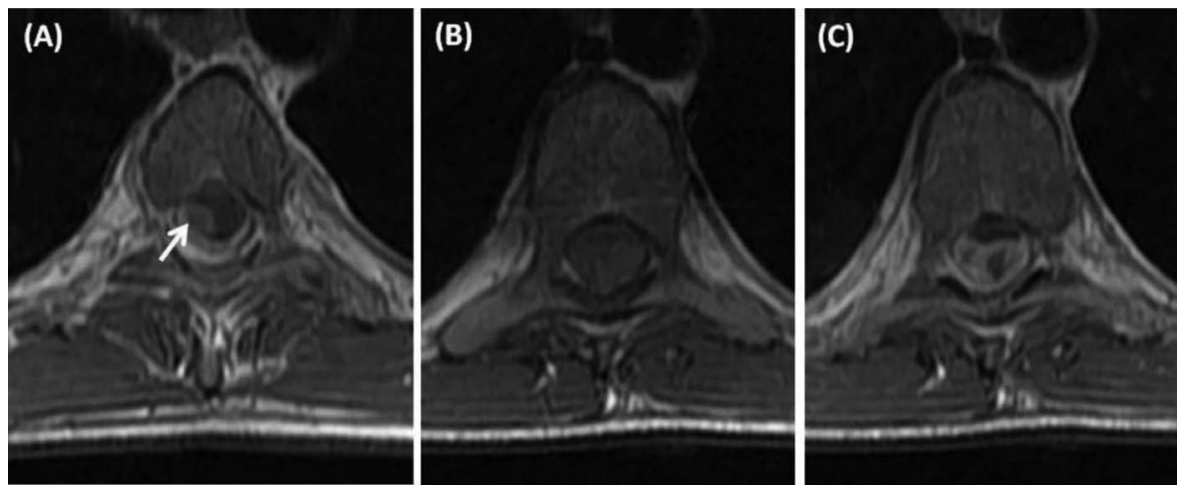

Figure 2 MRI dorsal spine axial images showing ring enhancing intramedullary lesion s/o tuberculoma $(T 1+C(A)$, arrow) and arachnoiditis with cord compression ( 11 -weighted image (B), $\mathrm{T} 1+\mathrm{C}(\mathrm{C})$ ). 
of corticosteroids and significant response in our patient favours the diagnosis of paradoxical reaction.

\section{Learning points}

- Development of new lesions or worsening of existing lesions is an indication of paradoxical response in CNS tuberculosis.

- Spinal cord tuberculosis as a paradoxical response should be considered as a rare but known possible complication of tuberculous meningitis.

- Corticosteroid is the recommended therapy along with antituberculous treatment.
Contributors RS was involved in data collection and drafting of manuscript, TC and RS contributed to the revision and concept of manuscript and VJ was involved in data collection and revision of manuscript.

Competing interests None.

Patient consent Obtained.

Provenance and peer review Not commissioned; externally peer reviewed.

\section{REFERENCES}

1 Skendros P, Kamaria F, Kontopoulos V, et al. Intradural extramedullary tuberculoma of spinal cord as a complication of tuberculous meningitis. Infection 2003;31:105-17.

2 Kumar R, Prakash M, Jha S. Paradoxical response to chemotherapy in neurotuberculosis. Pediatr Neurosurg 2006;42:214-22.

3 Roca B. Intradural extramedullary tuberculoma of the spinal cord: a review of reported cases. J Infect 2005;50:425-31.

Copyright 2014 BMJ Publishing Group. All rights reserved. For permission to reuse any of this content visit

http://group.bmj.com/group/rights-licensing/permissions.

BMJ Case Report Fellows may re-use this article for personal use and teaching without any further permission.

Become a Fellow of BMJ Case Reports today and you can:

- Submit as many cases as you like

- Enjoy fast sympathetic peer review and rapid publication of accepted articles

- Access all the published articles

- Re-use any of the published material for personal use and teaching without further permission

For information on Institutional Fellowships contact consortiasales@bmjgroup.com

Visit casereports.bmj.com for more articles like this and to become a Fellow 